\title{
Social Determinants and Risk Factors for Tuberculosis Patients: A Case Control Study at Health Services Applying Directly Observed Treatment Shortcourse (DOTS) in Bandar Lampung, Indonesia
}

\section{Dyah Wulan Sumekar Rengganis Wardani,1,2}

${ }^{1}$ Department of Community Medicine and Public Health, Faculty of Medicine, University of Lampung

${ }^{2}$ Research Center of Nutrition, Health and Herbal, Research and Community Service Institution, University of Lampung

\section{Abstract}

Tuberculosis (TB) control programs should place more emphasis on social determinants

Corresponding Author:

Dyah Wulan Sumekar Rengganis

Wardani

dwwardani@yahoo.com

Received: 21 January 2018

Accepted: 8 April 2018

Published: 17 May 2018

Publishing services provided by Knowledge $\mathrm{E}$

(c) Dyah Wulan Sumekar

Rengganis Wardani. This article

is distributed under the terms of

the Creative Commons

Attribution License, which

permits unrestricted use and

redistribution provided that the

original author and source are

credited.

Selection and Peer-review under the responsibility of the 2nd International Meeting of Public Health 2016 Conference Committee.

\section{G OPEN ACCESS}

which either directly or through TB risk factors can influence TB incidence. This study aims to identify the influence of social determinants and TB risk factors on TB incidence. A total of 238 smear-positive TB patients and 238 patients without TB were obtained from all smear-positive TB patients and TB suspects treated at Directly Observed Treatment Shortcourse (DOTS) health service facilities in Bandar Lampung, Indonesia. Data were collected by structured interview questions which were then analysed using both bi-variable chi-square analysis and multivariable logistic regression analysis. The results showed that social determinants (education and income per capita), housing conditions (ventilation and house density index), and household food security (food budget) proved to be significant influences on TB incidence. These indicators may explain the $50.7 \%$ variation in TB incidence. In conclusion, a TB control program should highlight social determinants, housing conditions, and household food security improvements. However, such a program would require the participation of all related institutions and should also be supported by appropriate government policies.

Keywords: tuberculosis, social determinants, housing conditions, household food security, health access, DOTS strategy

\section{INTRODUCTION}

Tuberculosis is a contagious disease caused by Mycobacterium tuberculosis. It is transmitted when an infectious person coughs, sneezes, or even talks in such a way that 
M. tuberculosis is spread through the air and inhaled by healthy individuals. About onethird of the world's population has either been infected by TB or become latent with TB infection. In certain conditions such as decreased immunity, latent TB infections can become active TB infections [24].

In 2013, there were an estimated nine million incidents of TB globally, or approximately 126 cases per 100000 people. A majority of cases (56\%) occurred in Asia, and Indonesia was one of the five countries with the highest rate of TB incidence (0.41 - 0.52 million cases) [27]. According to the World Health Organization (WHO), tuberculosis control, as defined by the 2015 Millennium Development Goal (MDG) of halting and reversing TB incidence, has been achieved in most countries but not in some high-burden countries such as Afghanistan, Bangladesh, Indonesia, and South Africa. To achieve MDG's next TB control target by 2050 - reducing TB cases to less than one per one million people per year - is a big challenge and especially so for high-burden countries [26].

To accelerate the decrease of incidence, TB control programs will 'move out of the TB box' and place more emphasis on social determinants [21]. Tuberculosis is closely related to social determinants, and it is well-known that social determinants directly or through TB risk factors influence TB spread [18]. According to WHO, social determinants include low education, unemployment, low income per capita, low social class, gender, and race [23]. These determinants also affect risk factors which increase exposure to infectious droplets and/or affect host defense such as the following: a) poor housing conditions (e.g. a lack of ventilation, overcrowding, and existence of indoor pollution); b) household food insecurity (e.g. reduced food budget, food diversity, and food quantity); c) poor access to health care (e.g. long distances to health care providers and limited availability of transportation); and d) unhealthy behavior (e.g. HIV status and alcohol abuse) [18]. Studying social determinants and risk factors for TB comprehensively requires identifying the significance of certain variables. This research study assesses the influence of social determinants and risk factors of TB as comprehensive variables rather than as partial variables as discussed by previous researchers $[7,13,15,29]$.

Bandar Lampung is the capital city of Lampung Province, Indonesia. In this city, there are twenty-seven primary health centers (PHC) and one general hospital that applied the Directly Observed Treatment Shortcourse (DOTS) strategy. According to the notification cases which were recorded by health services, while the cure rate for the period of $2011-2013$ has been maintained at $85 \%$, the notification cases during $2012-2014$ increased from 968 cases to $972[10,11]$. Lampung has been classified as 
one of the poorest provinces in Indonesia as well as the province with the poorest housing conditions [17].

In this study, all variables of the concerned determinants were analyzed to provide a comprehensive understanding. Knowledge of the influence of social determinants on the risk factors for TB incidence will be worthwhile to TB control programs, especially those focused on decreasing TB incidence.

\section{MATERIALS AND METHODS}

\subsection{Study Design}

This study was a case-control study that compared case and control groups to identify significant influences of social determinants and risk factors to TB.

\subsection{Study Site and Samples}

This research has been conducted at all health services that apply DOTS strategy in Bandar Lampung. The population studied by this research consisted of a case population and a control population. The case population consisted of all smear-positive TB patients recorded by health services during the period from January of 2012 through July of 2012. The control population consisted of all TB suspects who tested negative for TB as confirmed by negative microbiological analysis of sputum examinations and/or negative chest $X$-ray examinations. The samples size of both case and control groups consisted of 238 smear-positive TB patients and 238 patients without TB based on a samples calculation for case control study with a significance level of $95 \%$ and $80 \%$ power.

\subsection{Research Variables}

Research variables in this study consisted of indicators of social determinants, housing conditions, food security, and health access. Indicators for social determinants included education (length of education that has been achieved: $<9$ years and $>9$ years), occupation (unemployed, employed), income (income per capita: < US\$ 1,639, > US\$ 1,639), social class (having no productive assets, having $>1$ productive assets) $([3,9$, 23], Badan Pusat Statistik Provinsi Lampung, 2013). Indicators of housing conditions consisted of a house density index (house area divided by number of inhabitants: $<8$ 
$\mathrm{m}^{2},>8 \mathrm{~m}^{2}$ ), ventilation (percentage of house area with proper ventilation: $<20 \%$, $>$ $20 \%$ ), and indoor air pollution (>1 sources, none) $[5,17]$. Indicators of household food security consisted of food budget (monthly food budget for each person: < US\$30, $>$ US\$ 30), diet diversity (number of diet types in daily consumption: $<3,>3$ ), and food sufficiency (missed meal times and reduced meal portions, never missed meal times or reduced meal portions) (Badan Pusat Statistik Provinsi Lampung, 2013; [6]). Indicators of health access consisted of distance to health facility $(>5 \mathrm{~km},<5 \mathrm{~km})$ and transportation needs (yes, no) [4]. Based on observation of Bandar Lampung subjects, there were no differences according to race and gender as related to TB cases and there were no TB patients with HIV confections or who suffered from alcohol abuse. Therefore, those variables were not studied as part of this research [25].

\subsection{Data Collection and Analysis}

In this research, data was collected through direct interviews based on a designed questionnaire. Data was then analyzed using bi-variable analysis (chi square) and multivariable analysis (logistic regression) to simultaneously study the influence of each individual variable and identify significant variables affecting the TB cases. Enter method was used to perform logistic regression analysis in this research. In the first step of the method, variables with p value less than 0.25 in bi-variable analysis were followed with multivariable analysis. In the second step, variables with $p$ value of more than 0.05 were removed from the model one by one according to their $p$ values with the variables with the highest $p$ value removed first. The second step was ended when all variables had a $p$ value of less than 0.05 , and the resulting model was the final model [14].

\subsection{Ethical Clearance}

Ethical clearance for this study was obtained from the Medical and Health Research Ethics Committee, Faculty of Medicine, Gadjah Mada University, Indonesia. In this research, all involved respondents were asked to participate on a voluntary basis and received sufficient information to consider consent prior to the interview. 


\section{RESULTS AND DISCUSSIONS}

The bi-variable chi-square analysis shows that all research variables have a $p$ value of less than 0.05 except occupation, as presented in Table 1. Referring to these results, all variables other than occupation show a significant effect on TB occurrence. Diet diversity and housing density index were categorized as variables with the highest odds ratio (OR) among the other variables.

The results show that there were more respondents with lower education in the case group than in the control group. This logically correlated with the fact that more respondents in the case group had lower income per capita and fewer productive assets than the respondents in the control group. These conditions also correlated with the fact that respondents in the case group were more likely to have poorer housing conditions, less food security, and lower health care access than the respondents in the control group. Related research indicates that persons with more education also tend to have better occupations, higher incomes, and more productive assets than persons with lesser education [8].

Some research has shown that people with better social determinants tend to have better housing conditions, food security, and health access $[1,16,22]$. In this research, occupation was not a risk factor of TB since most of women in both the case group and the control group were housewives. Also, while distance to PHC and the availability of needed transportation were both significant to TB incidence, the significance values were slight and mostly correlated with where the concerned PHCs were located across the city. The longest distance reported by respondents to the nearest PHC is only about six kilometers.

Based on the multivariable analysis using logistic regression, our research shows that education, income per capita, ventilation, house density index, and food budget all significantly influence TB spread according to the last model (Table 2). The equation of the model was developed as follows: $-2.389+0.943$ Education + 1.339 Income per capita +1.023 Ventilation +1.328 House density index +0.692 Food budget. These variables explain the $50.7 \%$ variation of TB incidence.

Our findings suggest that social determinants (represented by education and income per capita), housing conditions (represented by ventilation and house density index), and household food security (represented by food budget) all influence TB incidence and explain the $50.7 \%$ variation in TB incidence. The remaining variation seems to be caused by other variables which are beyond the scope of this research. These results were consistent with the view that social determinants, either directly or through TB 
TABLE 1: Bivariable Analysis of Social Determinants and Risk Factors to TB.

\begin{tabular}{|c|c|c|c|c|c|}
\hline Variables & Cases & Controls & $\mathrm{OR}$ & $95 \% \mathrm{Cl}$ & $p$ value \\
\hline \multicolumn{6}{|l|}{ Education } \\
\hline$<9$ years & $84(77.1 \%)$ & $25(22.9 \%)$ & 4.647 & $2.840-7.603$ & $<0.001$ \\
\hline$>9$ years & $154(42.0 \%)$ & $213(58.0 \%)$ & & & \\
\hline \multicolumn{6}{|l|}{ Occupation } \\
\hline Unemployed & $90(49.2 \%)$ & $93(50.8 \%)$ & 0.948 & $0.655-1.372$ & 0.777 \\
\hline Employed & $148(50.2 \%)$ & $145(49.8 \%)$ & & & \\
\hline \multicolumn{6}{|l|}{ Income } \\
\hline$<$ US\$1,639 & $167(77.0 \%)$ & $50(23.0 \%)$ & 8.844 & $5.825-13.428$ & $<0.001$ \\
\hline$>$ US\$1,639 & $71(27.4 \%)$ & $188(72.6 \%)$ & & & \\
\hline \multicolumn{6}{|l|}{ Social classes } \\
\hline None & $183(70.9 \%)$ & $75(29.1 \%)$ & 7.231 & $4.814-10.863$ & $<0.001$ \\
\hline$>1$ productive assets & $55(25.2 \%)$ & $163(74.8 \%)$ & & & \\
\hline \multicolumn{6}{|l|}{ House density index } \\
\hline$<8 \mathrm{~m}_{2}$ & $162(79.8 \%)$ & $41(20.2 \%)$ & 10.242 & $6.643-15.791$ & $<0.001$ \\
\hline$>8 m_{2}$ & $76(27.8 \%)$ & $197(72,2 \%)$ & & & \\
\hline \multicolumn{6}{|l|}{ Ventilation } \\
\hline$<20 \%$ & $172(77.1 \%)$ & $51(22.9 \%)$ & 9.556 & $6.278-14.543$ & $<0.001$ \\
\hline$>20 \%$ & $66(26.0 \%)$ & $187(74.0 \%)$ & & & \\
\hline \multicolumn{6}{|c|}{ Indoor air pollution sources } \\
\hline$>1$ & $169(64.5 \%)$ & $93(35.5 \%)$ & 3.819 & $2.605-5.597$ & $<0.001$ \\
\hline None & $69(32.2 \%)$ & $145(67.8 \%)$ & & & \\
\hline \multicolumn{6}{|l|}{ Food budget } \\
\hline$<$ US\$30 & $222(58.7 \%)$ & $156(41.3 \%)$ & 7.239 & $4.110-12.941$ & $<0.001$ \\
\hline$>$ US\$30 & $16(16.3 \%)$ & $82(83.7 \%)$ & & & \\
\hline \multicolumn{6}{|l|}{ Diet diversity } \\
\hline$<2$ diet type & $235(87.0 \%)$ & $35(13.0 \%)$ & 13.506 & $4.093-44.570$ & $<0.001$ \\
\hline$>2$ diet type & $3(1.5 \%)$ & $203(98.5 \%)$ & & & \\
\hline \multicolumn{6}{|l|}{ Food sufficiency } \\
\hline No & $222(55.6 \%)$ & $177(44.4 \%)$ & 4.782 & $2.664-8.582$ & $<0.001$ \\
\hline Yes & $16(20.8 \%)$ & $61(79.2 \%)$ & & & \\
\hline \multicolumn{6}{|l|}{ Distance to PHC } \\
\hline$>5 \mathrm{~km}$ & $21(72.4 \%)$ & $8(27.6 \%)$ & 2.782 & $1.207-6.414$ & 0.021 \\
\hline$<5 \mathrm{~km}$ & $217(48.5 \%)$ & $230(51.5 \%)$ & & & \\
\hline \multicolumn{6}{|l|}{ Transportation need } \\
\hline Yes & $73(64.6 \%)$ & $40(35.4 \%)$ & 2.190 & $1.414-3.392$ & 0.001 \\
\hline No & $165(45.5 \%)$ & $198(54.5 \%)$ & & & \\
\hline \multicolumn{6}{|l|}{ OR: Odds ratio } \\
\hline $\mathrm{Cl}$ : Confidence interval & & & & & \\
\hline
\end{tabular}


TABLE 2: Multivariable Analysis of Social Determinants and Risk Factors to TB.

\begin{tabular}{l|c|c|c|c|}
\hline Variables & $\beta$ & $\mathrm{P}$ value & $\operatorname{Exp}(\beta)$ & $95 \% \mathrm{Cl}$ \\
\hline Education & 0.943 & 0,002 & 2.569 & $1.408-4.686$ \\
\hline Income per capita & 1.339 & $<0,001$ & 3.814 & $2.331-6.238$ \\
\hline Ventilation & 1.023 & $<0.001$ & 2.781 & $1.622-4.769$ \\
\hline House density index & 1.328 & $<0.001$ & 3.775 & $2.193-6.500$ \\
\hline Food budget & 0.692 & 0.047 & 1.997 & $1.011-3.945$ \\
\hline Constant & -2.389 & $<0.001$ & 0.092 & \\
\hline B: Beta & & & & \\
Exp (B): Exponent Beta & & & &
\end{tabular}

risk factors, influence TB incidence [18]. The findings of this research are also interrelated with the 'Stop TB Strategy' which states that TB control programs should address the needs of poor and vulnerable populations [28].

Moreover, a study on the effects of social determinant improvement in supporting TB control programs has been conducted in Lima, Peru. That study showed that social determinant improvement, namely the 'Fighting Poverty to Control TB Project', could decrease poverty while also supporting TB control programs. The project included improving access to training programs for workers, providing microcredit loans, and supporting development of microenterprises [12].

\section{CONCLUSIONS}

Based on our findings, TB control programs should highlight social determinant improvements such as housing condition and food security improvement. Some improvements will require the participation of all related institutions, and so both inter-institution coordination and mutual respect among involved stakeholders should be strengthened. This improvement needs to be supported by appropriate government policies for economic and social development with a greater emphasis on the most vulnerable people.

\section{ACKNOWLEDGEMENTS}

I would like to thank to all the health-services officers across Bandar Lampung and especially the TB taskforce for their support during the data collection. 


\section{References}

[1] Alexiu, Mircea, Ungureanu, et al. 2010. Impact of Education in Terms of Housing Opportunities. Procedia - Social and Behavioral Sciences 2: 1321-1325.

[2] Ariyanto. 2009. Aspek Kesejahteraan Masyarakat Dalam Konsumsi Pangan. http://www.bappenas .go.id/index.php/download_file/view/10158/1920/?\&kid=1397612052. (accessed July 29, 2014).

[3] Badan Perencana Pembangunan Nasional. 2010a. Pendidikan Dasar 9 Tahun. http://www.bappenas .go.id/get-file-server/node/585/. (accessed July 29, 2014)

[4] Badan Perencana Pembangunan Nasional. 2010b. Peningkatan Akses Masyarakat Terhadap Kesehatan Yang Lebih Berkualitas. http://www.bappenas.go.id/get-fileserver/node/8428. (accessed July 29, 2014).

[5] Balakrishnan, Kalpana, Mehta, et al. 2004. Indoor Air Pollution Associated with Household Fuel Use in India. An Exposure Assessment and Modeling Exercise in Rural Districts of Andhra Pradesh, India. Washington DC: The World Bank.

[6] Bickel, Gary, and Cook. 2000. Guide to Measuring Household Food Security, Revised 2000. Aleandria VA.

[7] Boccia, Hargreaves, De Stavola, et al. 2011. The Association Between Household Socioeconomic Position and Prevalent Tuberculosis in Zambia: A Case-Control Study. Plos One 6 (6).

[8] Braveman, Egerter, and Mockenhaupt. 2011. Broadening the Focus: The Need to Address the Social Determinants of Health. American Journal of Preventive Medicine 40: $\mathrm{S}_{4}-18$.

[9] CSDH. 2007. A Conceptual Framework for Action on the Social Determinants of Health. Geneva.

[10] Dinas Kesehatan Kota Bandar Lampung. 2010. Laporan Pencegahan Dan Pemberantasan (P2) Penyakit Tuberkulosis Tahun 2010. Bandar Lampung.

[11] Dinas Kesehatan Kota Bandar Lampung. 2011. Laporan Pencegahan Dan Pemberantasan (P2) Penyakit Tuberkulosis Tahun 2011. Bandar Lampung.

[12] Hargreaves, Boccia, Evans, et al. 2011. The Social Determinants of Tuberculosis: From Evidence to Action. American Journal of Public Health 101 (4): 654-62.

[13] Harling, Ehrlich, and Myer. 2008. The Social Epidemiology of Tuberculosis in South Africa: A Multilevel Analysis. Social Science \& Medicine 66: 492-505. 
[14] Hastono. 2001. Analisis Data. Jakarta: Fakultas Kesehatan Masyarakat UI.

[15] Hill, Jackson-Sillah, Donkor, et al. 2006. Risk Factors for Pulmonary Tuberculosis: A Clinic-Based Case Control Study in The Gambia. BMC Public Health 6 (156)

[16] Hur, Jin Jang, and Kyungwon Oh. 2011. Food and Nutrient Intakes According to Income in Korean Men and Women. Public Health and Research Perspectives 2 (3): $192-7$.

[17] Kementrian Kesehatan Republik Indonesia. 2010. Riset Kesehatan Dasar. Riskesdas 2010. Jakarta: Kementrian Kesehatan RI.

[18] Lönnroth. 2011. "Risk Factors and Social Determinants of TB. The Union NAR Meeting 24 Feb 2011." http://www.bc.lung.ca/association_and_services/documents/ KnutUnionNARTBriskfactorsanddeterminantsFeb2011.pdf. (accessed June 28, 2014).

[19] Lönnroth, Jaramillo, Williams, et al. 2009. Drivers of Tuberculosis Epidemics: The Role of Risk Factors and Social Determinants. Social Science \& Medicine 68: 22406.

[20] Pemerintah Daerah Propinsi Lampung. 2009. Ekonomi Makro Daerah. Bandar Lampung. http://www.old.lampungprov.go.id. (accessed June 28, 2014).

[21] Raviglione. 2009. TB Prevention, Care and Control, 2010-2015: Framing Global and WHO Strategic Priorities. In Report of The Ninth Meeting 9-11 November 2009. Geneva.

[22] Sabawoon, Wrishmeen, Sato, et al. 2011. Regional Differences in Delay to Tuberculosis Treatment in Afghanistan: A Cross-Sectional Study. Applied Geography 31: 1123-1131.

[23] Solar. 2010. A Conceptual Framework for Action on the Social Determinants of Health. Social Determinants of Health Discussion Paper 2 (Policy and Practice). Geneva.

[24] Thorn. 2007. Overcoming Tuberculosis: A Handbook for Patients. Geneva: Stop TB Partnership.

[25] Wardani. 2011. Pemanfaatan Variabel Pengaruh TB Dalam Prediksi Kejadian TB Di Kota Bandar Lampung. Research Report. University of Lampung. Bandar Lampung.

[26] WHO. 2012. "Global Tuberculosis Report 2012". Geneva.

[27] WHO. 2013. "Global Tuberculosis Report 2013". Geneva.

[28] WHO. 2014. "Global Tuberculosis Report 2014". Geneva.

[29] Ximenes, R.A. de Alencar, de Albuquerque, et al. 2009. Is It Better to Be Rich in A Poor Area or Poor in A Rich Area? A Multilevel Analysis of A Case-Control Study of 
Social Determinants of Tuberculosis. International Journal of Epidemiology 38 (5): $1285^{-1296 .}$ 